\title{
HYBRYDOWA METODA ELEMENTÓW SKOŃCZONYCH W MODELOWANIU OBRABIARKI KCI 210/280 NM
}

\author{
Janusz Grzywocz \\ Politechnika Śląska, Katedra Budowy Maszyn
}

Streszczenie. Celem artykułu jest zastosowanie hybrydowej metody elementów skończonych w modelowaniu obrabiarki KCI 210/280 NM. Z uwagi na innowacyjne zastosowanie hybrydowej metody elementów skończonych (HMES) w artykule przedstawiono sposób modelowania oraz wybrano warianty traktowania zespołów obrabiarki jako sztywnych oraz odksztatcalnych. Przedstawiono również wplyw wartości elementów sprężysto-tlumiących (EST) na otrzymywane wyniki. W badaniach przeprowadzono badanie sztywności statycznej obrabiarki wzdluz osi $x$ oraz y. W podsumowaniu porównano otrzymywane wyniki uzyskane hybrydowa (HMES) oraz klasyczna metoda elementów skończonych (MES) w odniesieniu do badań doświadczalnych.

Slowa kluczowe: metoda elementów skończonych, hybryda, modelowanie, sztywność obrabiarki

\section{HYBRID FINITE ELEMENT METHOD IN MODELING OF MACHINE TOOLS KCI 210/280 NM}

Abstract. This article presents use of hybrid finite element method in modeling of machine tool KCI 210/280 NM. In view of innovative use in modeling engineering hybrid finite element method (HFEM) in article presents way of modeling and next chosen variants treatment of group machine tool as rigid or flexible. Also presents impact of elastic-damper elements on the obtained results. In research perform conducted static stiffness along the $x$ and $y$ - axis machine tool. In conclusion the obtained results were compared hybrid (HFEM) and classical finite element method (FEM) for the experimental research.

Keywords: finite element method, hybrid, modeling, stiffness of machine tools

\section{Wstęp}

Zastosowanie klasycznej metody elementów skończonych (MES) polegającej na podziale (dyskretyzacji) badanego modelu geometrycznego za pomocą odkształcalnych elementów skończonych łączących się w węzłach [5] staje się znacznie utrudnione (czasochłonne) w przypadku tak złożonych maszyn jakim są obrabiarki. Przyjmuje się, że jednym z rozwiązań tego problemu jest zastosowanie hybrydowej metody elementów skończonych.

Przez pojęcie hybrydowej metody elementów skończonych rozumie się rozpatrywanie $\mathrm{w}$ badanym modelu geometrycznym obrabiarki sztywnych oraz odkształcalnych zespołów obrabiarki. Zatem model obrabiarki może uwzględniać zarówno zespoły sztywne (jak np. zespoły korpusowe) oraz zespoły modelowane podatnymi lub sztywnymi elementami skończonymi. Podejście takie wymaga opracowania sposobów połączenia zespołów obrabiarki odpowiednimi więzami kinematycznymi. Jak wykazano w pozycjach literaturowych [2, 6] metoda HMES jest stosowana w przypadku modeli wielkogabarytowych jak np. okręty, samoloty, żurawie, dźwigi czy obrabiarki.

\section{Opis modelu geometrycznego obrabiarki}

W oparciu o udostępnioną dokumentację konstrukcyjną w Katedrze Budowy Maszyn oraz szczegółowy opis zawarty w artykule [1] utworzony został model geometryczny obrabiarki wielkogabarytowej, wykorzystując zaawansowany system wspomagania prac inżynierskich Catia v5. Model geometryczny obrabiarki został przedstawiony na rys. 1 z uwzględnieniem poszczególnych elementów konstrukcyjnych.

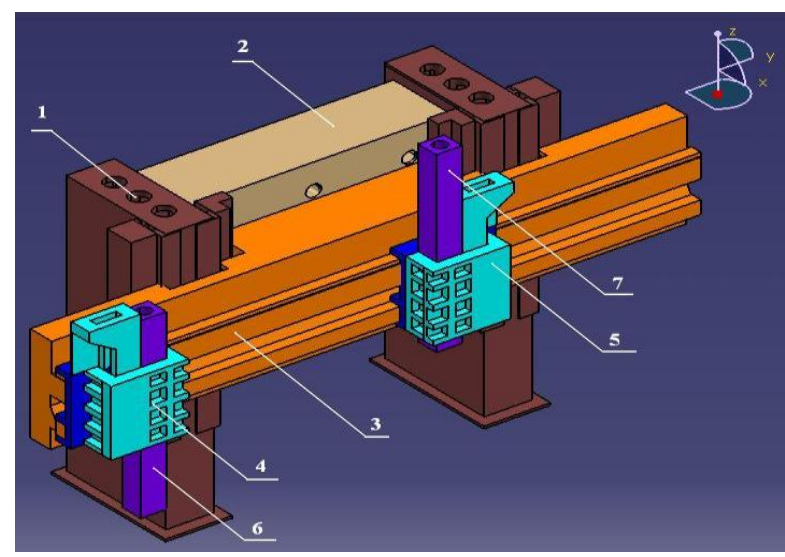

Rys. 1. Model geometryczny obrabiarki KCI 210/280 NM
W skład modelu geometrycznego wchodzą następujące elementy konstrukcyjne: 1 - stojak, 2 - belka wiążąca, 3 - belka suportowa. 4 - prowadnica I, 5 - prowadnica II, 6 - suwak narzędziowy lewy, 7 - suwak narzędziowy prawy.

\subsection{Badanie sztywności statycznej obrabiarki}

Badanie sztywności statycznej obrabiarki jest istotną informacją dla technologa, ponieważ określa się przemieszczenia względne wywołane siłami skrawania $w$ punkcie styku wierzchołka narzędzia skrawającego z przedmiotem obrabianym. Dzięki temu możliwe jest oszacowanie błędu wykonania przedmiotu obrabianego.

Celem przeprowadzanych badań jest wyznaczenie wskaźników sztywności obrabiarki pracującej przy różnym wysuwie suwaka narzędziowego, tj. od 250 do $1200 \mathrm{~mm}$. Suwak narzędziowy prawy obciążono składową siłą skrawania w kierunku osi x, a następnie osi y o wartości 10000 N. Wskaźniki sztywności statycznej dla kierunku osi $\mathrm{x}$, a następnie y wyznacza się z zależności (1):

$$
c=\frac{F}{\delta},
$$

gdzie: $F$ - składowa siła skrawania wzdłuż osi x oraz y $[\mathrm{N}]$, $\delta$ - przemieszczenie wywołane składową siłą skrawania [mm], $c$ - wskaźnik sztywności statycznej [N/mm].

Model geometryczny obrabiarki $\mathrm{z}$ określeniem warunków brzegowych, czyli uwzględnieniem składowych sił skrawania działających wzdłuż kierunku osi $\mathrm{x}$, a następnie y oraz odebraniu stopni swobody na elementach stojaka przedstawiono na rys. 2 .

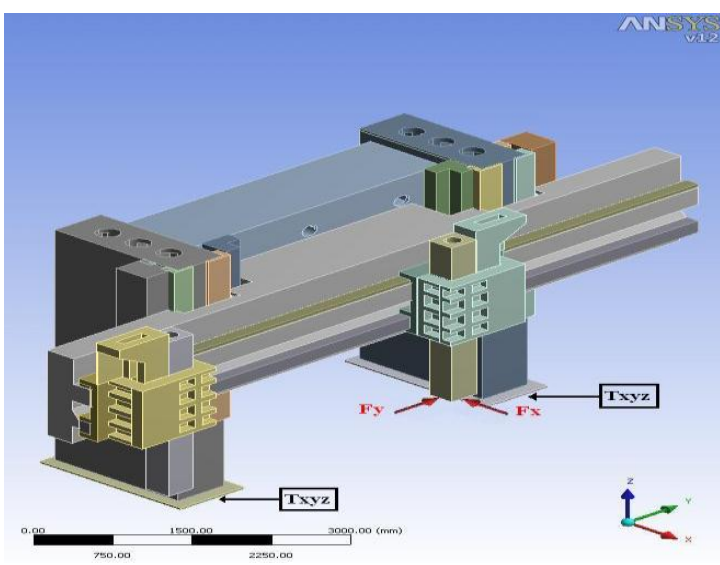

Rys. 2. Ustalenie warunków brzegowych obrabiarki KCI 210/280 NM 


\subsection{Dobór parametrów sztywności i tlumienia}

Istotnym $\mathrm{z}$ punktu widzenia możliwości przeprowadzania symulacji inżynierskich jest konieczność ustalania więzów kinematycznych między podatnymi a sztywnymi elementami skończonymi. W odniesieniu do hybrydowej metody elementów skończonych wykorzystano $\mathrm{z}$ biblioteki ANSYS elementy sprężysto-tłumiące. W modelu obliczeniowym własności sprężyste oraz dyssypacyjne każdego elementu sprężystothumiącego opisywane są przez macierz bloków sztywności oraz thumienia. W Katedrze Budowy Maszyn utworzono aplikację o nazwie "KBM - HMES" wspomagającą zaawansowane prace inżynierskie CAE w celu wyznaczania wartości współczynników sztywności i thumienia, a następnie zaimplementowania do systemu ANSYS. Zależności określające wartości współczynników sztywności i tłumienia (2) dla przypadku zginania dobrano na podstawie zaleceń zawartych w literaturze [4]:

$$
C_{k 5}=\frac{E \cdot J_{2}}{\Delta l}, \quad B_{k 5}=\frac{\eta \cdot J_{2}}{\Delta l}
$$

gdzie: $E$ - moduł Younga [MPa], $J_{2}$ - moment bezwładności przekroju poprzecznego wzdłuż osi $\mathrm{y}_{\mathrm{k} 2}\left[\mathrm{~m}^{4}\right], \Delta l$ - długość fragmentu sztywnego elementu skończonego $[\mathrm{m}], \eta$ - stała materiałowa thumienia normalnego.

Przykładowy schemat odkształceń przy zginaniu sztywnego elementu skończonego wzdłuż osi $\mathrm{y}_{\mathrm{k} 2}$ przedstawiono na rys. $3 a \quad z$ kolei schemat zastępczy elementu spreżysto-tłumiącego na rys. $3 \mathrm{~b}$.

a)

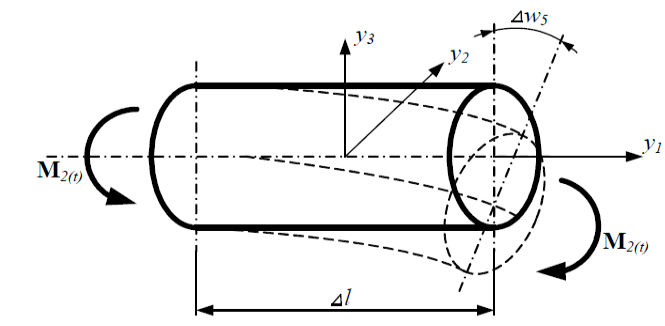

b)

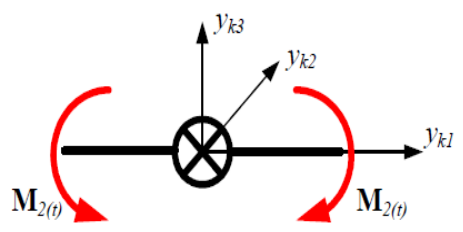

Rys. 3. Schemat odksztatceń przy zginaniu sztywnego elementu skończonego: a) Fragment belki dla przyktadowego sztywnego elementu skończonego dla zginania wzdluż osi $y_{k 2}$, b) Schemat zastępczy elementu spreżysto-tlumiacego dla zginania wzdluż osi $y_{k 2}$

\section{Algorytm postępowania podczas obliczeń}

Badania sztywności statycznej obrabiarki KCI 210/280 NM przeprowadzono w systemie ANSYS. Istotnym etapem przeprowadzania badań symulacyjnych jest zintegrowanie systemu ANSYS ze środowiskiem Catia v5 w celu importu gotowego modelu CAD według poniższego schematu:

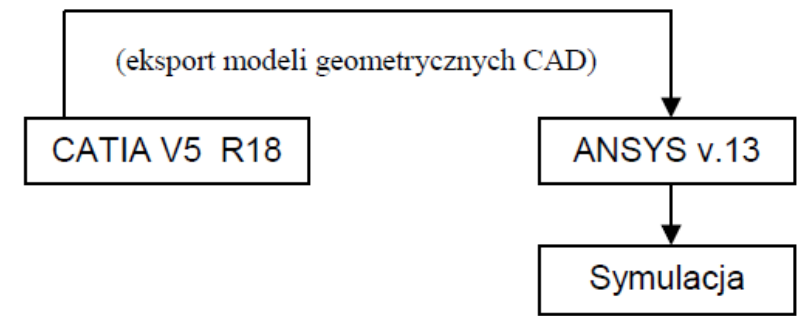

Algorytm postępowania w przypadku badania wskaźników sztywności statycznej przy wykorzystaniu systemu ANSYS hybrydową metodą elementów skończonych przedstawiono na schemacie poniżej:

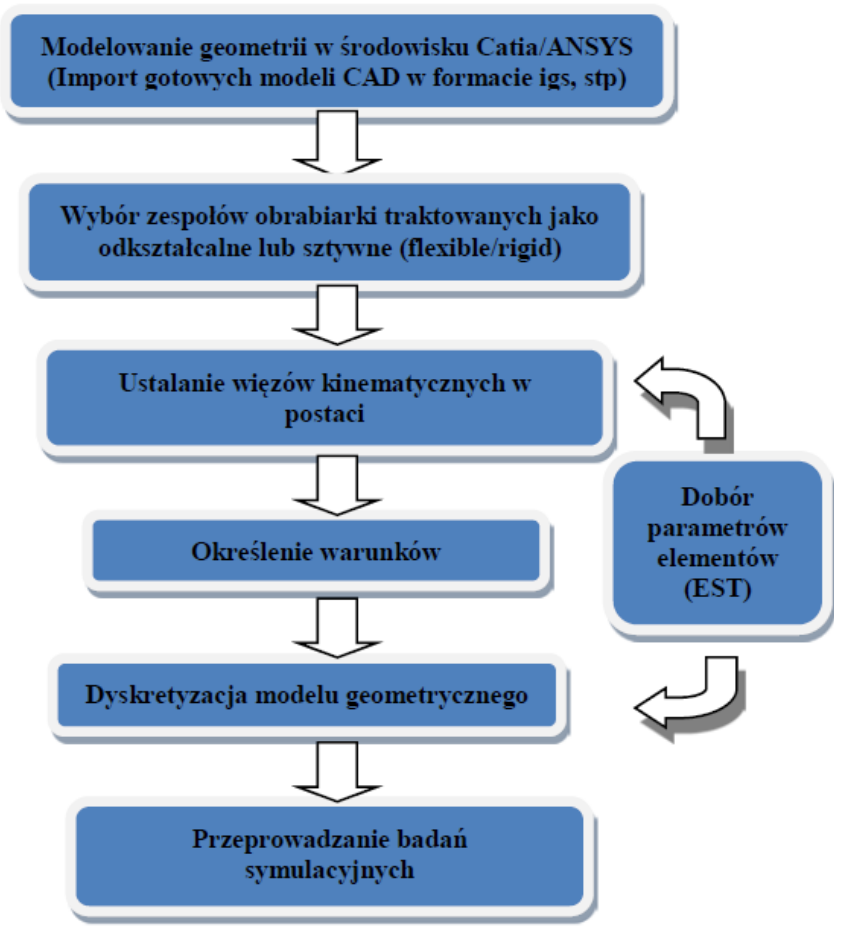

\section{Wyniki badań symulacyjnych}

Badania przeprowadzano dla minimalnego i maksymalnego wysuwu suwaka narzędziowego obrabiarki (od 250 do $1200 \mathrm{~mm}$ ) pod obciążeniem wzdłuż kierunku osi $\mathrm{x}$, a następnie y wzdłuż kierunku działania siły. W ramach badań założono następujące warianty traktowania zespołów sztywnych obrabiarki:

1) wariant I - sztywna belka wiążąca,

2) wariant II - sztywne stojaki,

3) wariant III - sztywne stojaki + belka wiążąca (korpus),

4) wariant IV - sztywna belka wspornikowa,

5) wariant $\mathbf{V}$ - sztywna belka wspornikowa + korpus.

$\mathrm{Z}$ uwagi na kolejne warianty traktowania sztywnych zespołów obrabiarki, odpowiednio zmieniała się ilość elementów spreżystothumiących, co przedstawiono $\mathrm{w}$ tabeli 1 .

Tabela 1. Ilość elementów sprężysto-tlumiacych zastosowanych podczas badań

\begin{tabular}{|c|c|c|c|c|c|}
\hline & Wariant 1 & Wariant 2 & Wariant 3 & Wariant 4 & Wariant 5 \\
\hline Ilość EST & 2 & 2 & 4 & 2 & 6 \\
\hline Ilość SES & 1 & 2 & 3 & 1 & 4 \\
\hline $\begin{array}{c}\text { Oznaczenie } \\
\text { EST }\end{array}$ & I-II & III-IV & $\begin{array}{c}\text { I-II, } \\
\text { III-IV }\end{array}$ & V-VI & $\begin{array}{c}\text { I-II, III- } \\
\text { IV, V-VI }\end{array}$ \\
\hline
\end{tabular}

W tabeli 2 zestawiono wartości wskaźników sztywności dla poszczególnych elementów sprężysto-tłumiących uzyskane w aplikacji "KBM-HMES" dla danego sztywnego zespołu obrabiarki.

Tabela 2. Wartości wspótczynników sztywności

\begin{tabular}{|c|c|c|c|c|c|c|}
\hline & $\begin{array}{c}\mathbf{C k}_{1} \\
{[\mathbf{N} / \mathbf{m m}]}\end{array}$ & $\begin{array}{c}\mathbf{C k}_{\mathbf{2}} \\
{[\mathbf{N} / \mathbf{m m}]}\end{array}$ & $\begin{array}{c}\mathbf{C k}_{\mathbf{3}} \\
{[\mathbf{N} / \mathbf{m m}]}\end{array}$ & $\begin{array}{c}\mathbf{C k}_{\mathbf{4}} \\
{[\mathbf{N} / \mathbf{m m}]}\end{array}$ & $\begin{array}{c}\mathbf{C k}_{\mathbf{5}} \\
{[\mathbf{N} / \mathbf{m m}]}\end{array}$ & $\begin{array}{c}\mathbf{C k}_{\mathbf{6}} \\
{[\mathbf{N} / \mathbf{m m}]}\end{array}$ \\
\hline $\begin{array}{c}\text { Belka } \\
\text { wiążąca } \\
\text { (I-II) }\end{array}$ & $23 \cdot 10^{10}$ & $21 \cdot 10^{9}$ & $21 \cdot 10^{9}$ & $11 \cdot 10^{12}$ & $16 \cdot 10^{10}$ & $23 \cdot 10^{11}$ \\
\hline $\begin{array}{c}\text { Stojak } \\
\text { (III-IV) }\end{array}$ & $42 \cdot 10^{9}$ & $10 \cdot 10^{10}$ & $10 \cdot 10^{10}$ & $64 \cdot 10^{8}$ & $72 \cdot 10^{9}$ & $13 \cdot 10^{8}$ \\
\hline $\begin{array}{c}\text { Belka } \\
\text { wsporn. } \\
\text { (V-VI) }\end{array}$ & $52 \cdot 10^{9}$ & $40 \cdot 10^{9}$ & $40 \cdot 10^{9}$ & $15 \cdot 10^{12}$ & $13 \cdot 10^{10}$ & $30 \cdot 10^{11}$ \\
\hline
\end{tabular}


Z kolei w tabeli 3 zestawiono wartości wskaźników tłumienia dla poszczególnych elementów sprężysto-tłumiących uzyskane w aplikacji "KBM-HMES" dla danego sztywnego zespołu obrabiarki.

Tabela 3. Wartości wspótczynników thumienia

\begin{tabular}{|c|c|c|c|c|c|c|}
\hline & $\begin{array}{c}\mathbf{B k}_{\mathbf{1}} \\
{[\mathbf{N} / \mathbf{m m} \cdot \mathbf{s}]}\end{array}$ & $\begin{array}{c}\mathbf{B k}_{\mathbf{2}} \\
{[\mathbf{N} / \mathbf{m m} \cdot \mathbf{s}]}\end{array}$ & $\begin{array}{c}\mathbf{B k}_{\mathbf{3}} \\
{[\mathbf{N} / \mathbf{m m} \cdot \mathbf{s}]}\end{array}$ & $\begin{array}{c}\mathbf{B k}_{\mathbf{4}} \\
{[\mathbf{N} / \mathbf{m m} \cdot \mathbf{s}]}\end{array}$ & $\begin{array}{c}\mathbf{B k}_{\mathbf{5}} \\
{[\mathbf{N} / \mathbf{m m} \cdot \mathbf{s}]}\end{array}$ & $\begin{array}{c}\mathbf{B k}_{\mathbf{6}} \\
{[\mathbf{N} / \mathbf{m m} \cdot \mathbf{s}]}\end{array}$ \\
\hline $\begin{array}{c}\text { Belka } \\
\text { wiążąca } \\
\text { (I-II) }\end{array}$ & $69 \cdot 10^{4}$ & $68 \cdot 10^{6}$ & $68 \cdot 10^{6}$ & $14 \cdot 10^{9}$ & $1768 \cdot 10^{4}$ & $26 \cdot 10^{5}$ \\
\hline $\begin{array}{c}\text { Stojak } \\
\text { (II-IV) }\end{array}$ & $35 \cdot 10^{5}$ & $34 \cdot 10^{7}$ & $34 \cdot 10^{7}$ & $27 \cdot 10^{5}$ & $81 \cdot 10^{4}$ & $14 \cdot 103^{7}$ \\
\hline $\begin{array}{c}\text { Belka } \\
\text { wsporni. } \\
\text { (V-VI) }\end{array}$ & $13 \cdot 10^{5}$ & $12 \cdot 10^{7}$ & $12 \cdot 10^{7}$ & $23 \cdot 10^{10}$ & $15 \cdot 10^{5}$ & $34 \cdot 10^{6}$ \\
\hline
\end{tabular}

\subsection{Badanie wskaźników sztywności wzdłuż kierunku osi $x$ HMES}

W tabeli 4 zestawiono wartości przemieszczeń oraz wyznaczono wskaźniki sztywności statycznej obrabiarki dla wysuwu suwaka 250 i $1200 \mathrm{~mm}$ przy różnych wariantach zespołów sztywnych.

Tabela 4. Wartości przemieszczeń oraz wskaźników sztywności wzdluż osi x

\begin{tabular}{|c|c|c|c|c|}
\hline \multirow{2}{*}{$\begin{array}{c}\text { Metoda } \\
\text { obliczeń }\end{array}$} & $\mathbf{2 5 0} \mathbf{~ m m}$ & $\mathbf{1 2 0 0} \mathbf{~ m m}$ & $\mathbf{2 5 0} \mathbf{~ m m}$ & $\mathbf{1 2 0 0} \mathbf{~ m m}$ \\
\cline { 2 - 5 } & $\boldsymbol{\delta}_{\mathbf{r z}}[\mathbf{m m}]$ & $\boldsymbol{\delta}_{\mathbf{r z}}[\mathbf{m m}]$ & $\mathbf{c}[\mathbf{k N} / \mathbf{m m}]$ & $\mathbf{c}[\mathbf{k N} / \mathbf{m m}]$ \\
\hline HMES - w I & 0,0515 & 0,147 & 194,17 & 68,02 \\
\hline HMES - w II & 0,0535 & 0,155 & 186,91 & 64,52 \\
\hline HMES - w III & 0,0526 & 0,147 & 190,11 & 67,98 \\
\hline HMES - w IV & 0,0546 & 0,16 & 183,15 & 62,3 \\
\hline HMES - w V & 0,056 & 0,161 & 178,57 & 62,11 \\
\hline MES & 0,0495 & 0,127 & 202,02 & 78,74 \\
\hline Dośw. & 0,058 & 0,165 & 170 & 60 \\
\hline
\end{tabular}

$\mathrm{Na}$ rysunku 4 zestawiono otrzymane wskaźniki sztywności statycznej obrabiarki wzdłuż składowej siły skrawania w osi x.

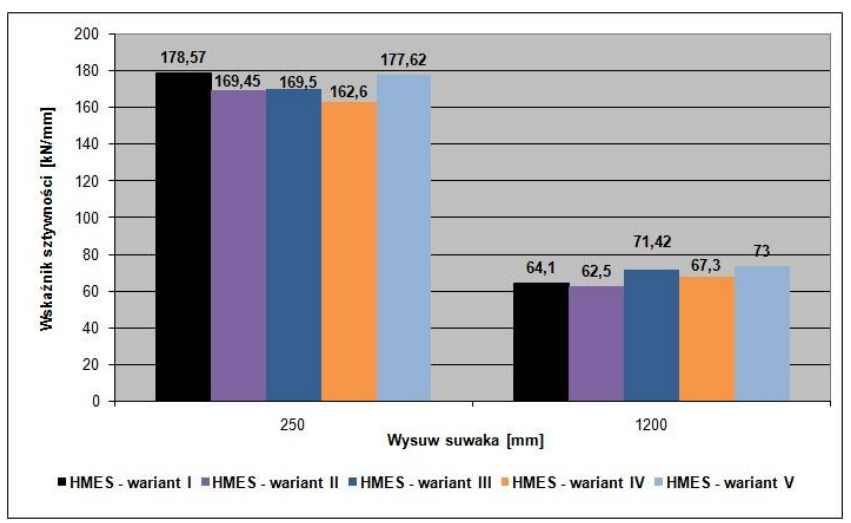

Rys. 4. Zestawienie wskaźników sztywności wzdluż osi $x$ obrabiarki KCI 210/280 HMES

\subsection{Badanie wskaźników sztywności wzdłuż kierunku osi y HMES}

$\mathrm{Z}$ kolei w tabeli 5 zestawiono wartości przemieszczeń oraz wyznaczono wskaźniki sztywności statycznej obrabiarki dla wysuwu suwaka 250 i $1200 \mathrm{~mm}$ przy różnych wariantach zespołów sztywnych.

Tabela 5. Wartości przemieszczeń oraz wskaźników sztywności wzdłuż osi y

\begin{tabular}{|c|c|c|c|c|}
\hline \multirow{2}{*}{$\begin{array}{c}\text { Metoda } \\
\text { obliczeń }\end{array}$} & $\mathbf{2 5 0} \mathbf{~ m m}$ & $\mathbf{1 2 0 0} \mathbf{~ m m}$ & $\mathbf{2 5 0} \mathbf{~ m m}$ & $\mathbf{1 2 0 0} \mathbf{~ m m}$ \\
\cline { 2 - 5 } & $\boldsymbol{\delta}_{\mathbf{r z}}[\mathbf{m m}]$ & $\boldsymbol{\delta}_{\mathbf{r z}}[\mathbf{m m}]$ & $\mathbf{c}[\mathbf{k N} / \mathbf{m m}]$ & $\mathbf{c}[\mathbf{k N} / \mathbf{m m}]$ \\
\hline HMES - wI & 0,056 & 0,124 & 178,57 & 64,1 \\
\hline HMES - w II & 0,059 & 0,166 & 169,45 & 62,5 \\
\hline HMES - w III & 0,059 & 0,148 & 169,5 & 71,42 \\
\hline HMES - w IV & 0,0615 & 0,1486 & 162,6 & 67,3 \\
\hline HMES - w V & 0,0563 & 0,156 & 177,62 & 73 \\
\hline MES & 0,0493 & 0,15 & 223,71 & 66,66 \\
\hline Dośw. & 0,057 & 0,145 & 175 & 70 \\
\hline
\end{tabular}

Poniżej na rysunku 5 zestawiono otrzymane wskaźniki sztywności statycznej obrabiarki wzdłuż składowej siły skrawania w osi y.

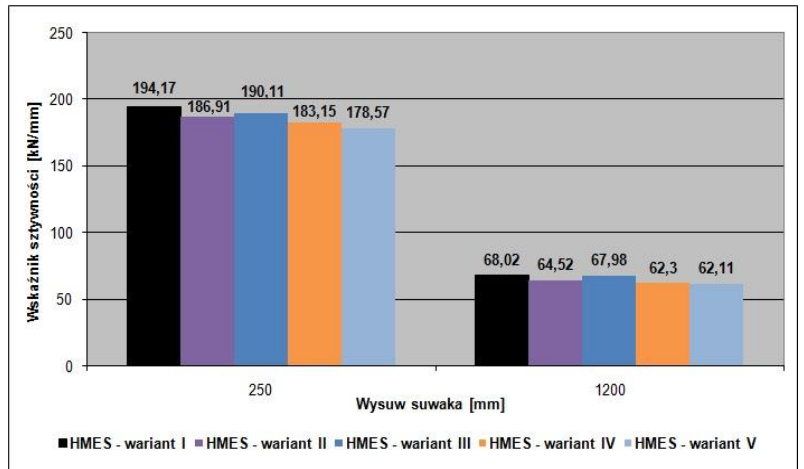

Rys. 5. Zestawienie wskaźników sztywności wzdluż osi y obrabiarki KCI 210/280 HMES

Na rysunku 6 przedstawiono wybraną symulację obrabiarki KCI 210/280 NM przy wysuwie suwaka $250 \mathrm{~mm}$ dla wariantu 3.

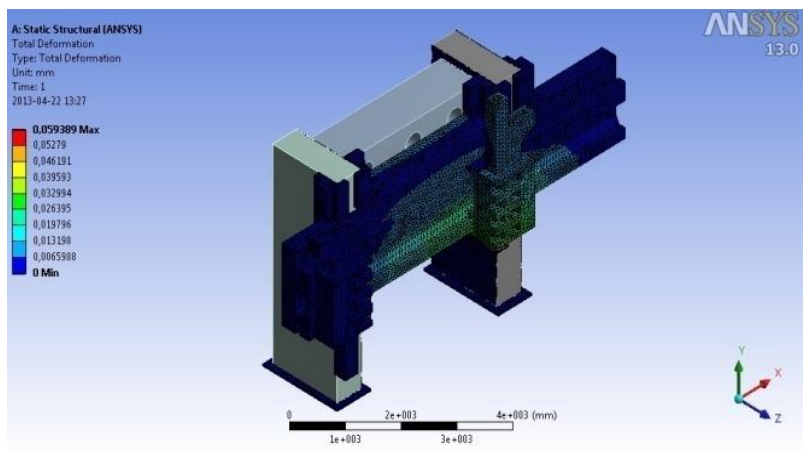

Rys. 6. Otrzymana symulacja $w$ kierunku osi x przy wysuwie suwaka $250 \mathrm{~mm}$ obrabiarki KCI 210/280 NM dla wariantu 3

\subsection{Badanie wskaźników sztywności MES}

Badania wskaźników sztywności statycznej obrabiarki przeprowadzono w systemie ANSYS również klasyczną metodą MES w celu porównania otrzymanych wyników. Na rysunku 7 zestawiono otrzymane wskaźniki sztywności statycznej przy różnym wysuwie suwaka narzędziowego, tj. od 250 do $1200 \mathrm{~mm}$.
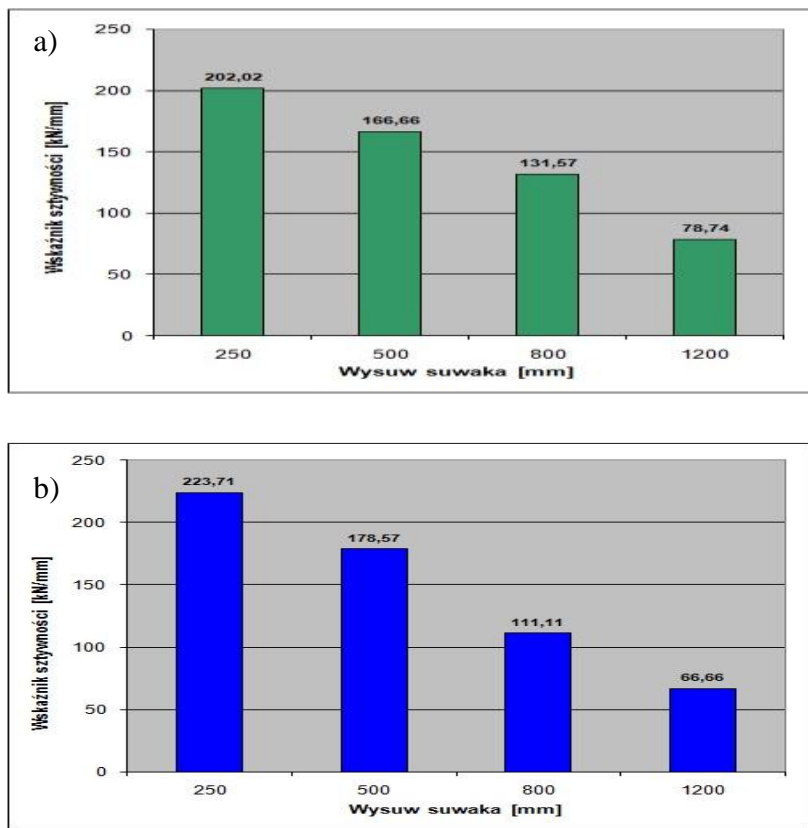

Rys. 7. Zestawienie wskaźników sztywności obrabiarki KCI 210/280 MES a) wzdtuż osi $x, b$ ) wzdtuż osi 


\subsection{Badanie wskaźników sztywności doświadczalnie}

W celu weryfikacji otrzymanych wyników metodami numerycznymi $\mathrm{z}$ badaniami doświadczalnymi, zrealizowano badania wskaźników sztywności statycznej obrabiarki metodą konwencjonalną, szczegółowo opisanej w pracy doktorskiej [2]. Wyniki zestawiono na rys. 8.
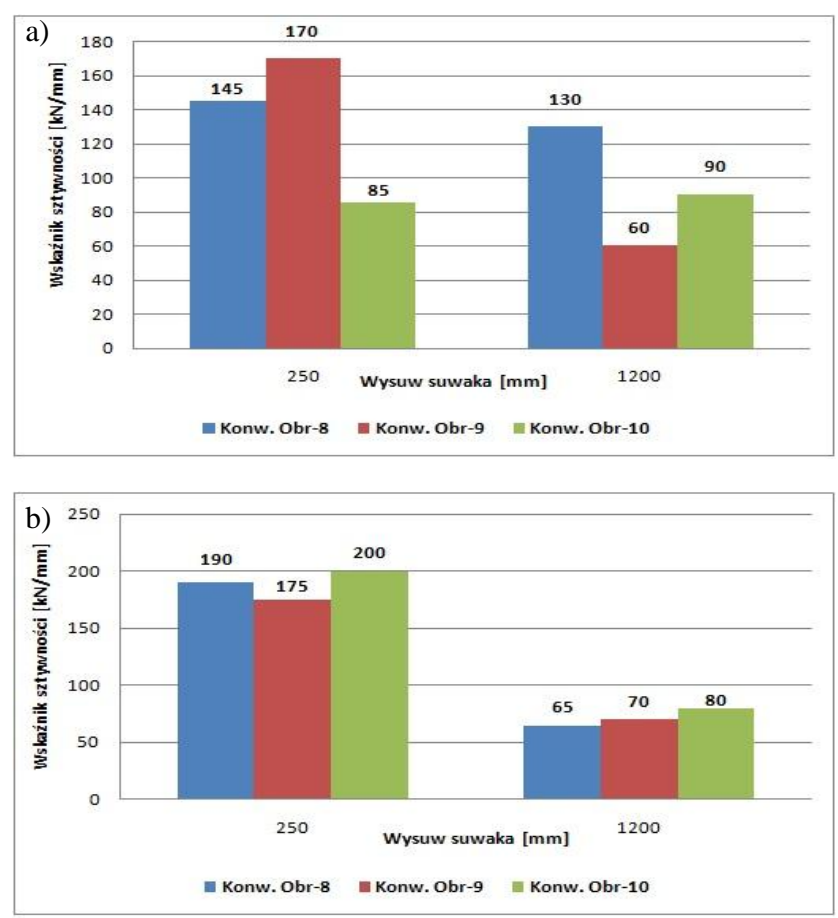

Rys. 8. Wyniki badań doświadczalnych obrabiarki a) $w$ kierunku osi $x$ b) w kierunku osi $y$

\subsection{Porównanie wyników}

W celu porównania oraz weryfikacji otrzymanych wyników metodą HMES, MES oraz doświadczalną zestawiono otrzymane wskaźniki sztywności statycznej obrabiarki na rys. 9.
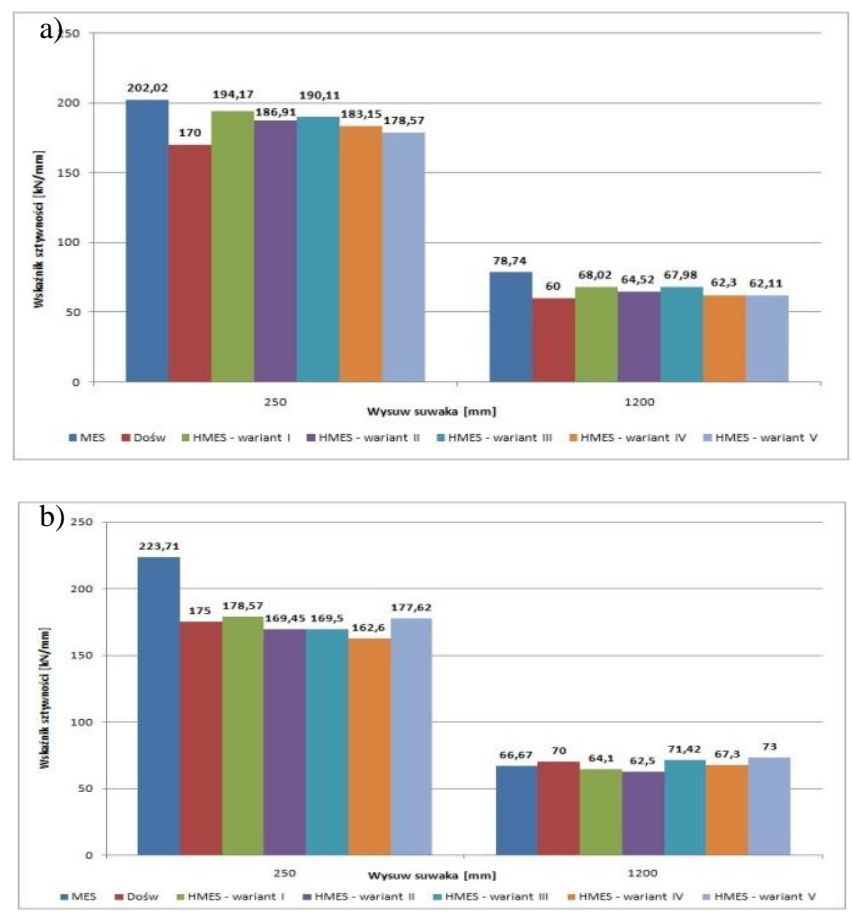

Rys. 9. Porównanie otrzymanych wskaźników sztywności obrabiarki KCI 210/280 NM a) wzdluż osi x, b) wzdluż osi y

\section{Wnioski}

Z przeprowadzonych badań wynika, że hybrydowa metoda elementów skończonych (HMES) może być stosowana $\mathrm{w}$ analizach numerycznych. Zakres zastosowań wykorzystania metody HMES obejmuje przede wszystkim modele geometryczne wielkogabarytowe jak np. obrabiarki.

Porównując otrzymane wyniki $\mathrm{w}$ analizach numerycznych otrzymano różnicę nie przekraczającą $5 \%$ wartości w porównaniu do wyników otrzymanymi metodą MES. W klasycznej metodzie MES wystąpił problem z dyskretyzacją typu siatki "HEX", szczególnie dla zespołów obrabiarki wchodzących w zestaw korpusu, jak np. belka wiążąca oraz stojaki. Liczne użebrowania oraz sfazowania tych elementów doprowadziły do konieczności dyskretyzowania modelu geometrycznego siatką typu "TETRA". Wykorzystując metodę HMES wyeliminowano konieczność dyskretyzowania tych zespołów obrabiarki, narażonych na zwiększoną wartość zagęszczenia siatki, dodatkowo czas przeprowadzanych analiz był znacznie krótszy.

Otrzymane wyniki są zadawalające o czym świadczy fakt uzyskania wyników metodą HMES zbliżonych do badań doświadczalnych. Dodatkową zaletą metody HMES jest możliwość wykorzystywania języków programowania wysokiego rzędu wspomagających pracę inżynierów-konstruktorów. Kolejnym etapem badań jest konieczność przeprowadzania analizy wrażliwości w celu określenia zmian wartości parametrów wejściowych na otrzymywane wyniki.

\section{Literatura}

[1] Grzywocz J.: Analiza wpływu uproszczeń modelu geometrycznego obrabiarki KCI 210/280 NM na wyniki uzyskane metoda elementów skończonych. Prace Naukowe Katedry Budowy Maszyn, nr 2/2011, poz. 11.

[2] Kono D., Lorentzer T., Weikert, S, Wegener K.: Comparison of rigid body mechanics and finite element method for machine tool evaluation.

[3] Kaźmierczak M.: Praca doktorska: Metodyka badań sztywności statycznej obrabiarek ciężkich w warunkach przemysłowych. Gliwice 2005.

[4] Kruszewski J., Sawiak S., Wittbrodt E.: Wspomaganie komputerowe CAD/CAM. Metoda sztywnych elementów skończonych w dynamice konstrukcji. WNT, Warszawa, 1999.

[5] Łaczek S.: Modelowanie i analiza konstrukcji w systemie MES - ANSYS v.11. PK, Kraków 2011.

[6] Mattern S., Blankerhorn G., Schweizerhof K.: Comparison of building collapse simulation results from finite element and rigid body models, 2006.

[7] www.ansys.com

\section{Mgr inż. Janusz Grzywocz \\ e-mail: jgrzywocz@ polsl.pl}

Absolwent Wydziału Mechaniczno-Technologicznego o specjalności Technologia Budowy Maszyn Politechniki Śląskiej w Gliwicach. Od roku 2010 doktorant w Katedrze Budowy Maszyn na stanowisku asystenta profesora. Działalność naukowa skupia się w obszarach modelowania inżynierskiego oraz technik komputerowych w budowie i diagnostyce maszyn. Dodatkowy zakres zainteresowań naukowych to analizy MES, programowanie maszyn sterowanych numerycznie, programowanie $w$ językach $\mathrm{c}++$ fortran, java script oraz diagnostyka i automatyzacja maszyn i urządzeń

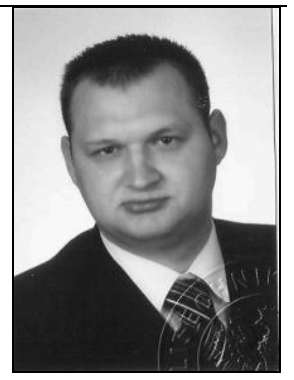

